\title{
Лештаев М.В., Смывин Р.В. \\ Анализ внедрения и применения новых физических упражнений в войсках национальной гвардии Российской Федерации
}

Новосибирский военный институт имени генерала армии И. К. Яковлева войск национальной гвардии Российской Федераџии

(Россия, Новосибирск)

doi: $10.18411 / \mathrm{j}-05-2021-234$

\section{Аннотация}

В статье рассмотрен анализ внедрения и применения новых физических упражнений в войсках национальной гвардии Российской Федерации. Дана краткая характеристика порядка применения физических упражнений, показаны положительные и отрицательные стороны их влияния на организм военнослужащих, сотрудников войск национальной гвардии Российской Федерации. Статья может быть полезна специалистам физической подготовки и спорта, командирам подразделений проводящих занятия по физической подготовке.

Ключевые слова: анаэробный тип, мышечная деятельность, мышечная система, физическая подготовленность, аэробный тип, функциональное многоборье, энергообеспечение, использование комплексов, смешанный тип, комплекс, подтягивание.

\section{Abstract}

The article considers the analysis of the introduction and application of new physical exercises in the troops of the National Guard of the Russian Federation. A brief description of the procedure for the use of physical exercises is given, the positive and negative aspects of their effect on the body of military personnel, employees of the National Guard troops of the Russian Federation are shown. The article can be useful for specialists in physical training and sports, commanders of units conducting physical training classes.

Keywords: anaerobic type, muscular activity, muscular system, physical fitness, aerobic type, functional all-around, energy supply, use of complexes, mixed type, complex, pull-up.

Физическая культура в нашей стране служит интересам всего общества и является частью культуры, представляющей собой совокупность ценностей, норм и знаний, используемых в целях физического, интеллектуального развития способностей граждан, совершенствования их двигательной активности и формирования здорового образа жизни, социальной адаптации, путем физического воспитания, и физического развития. Занятия физической подготовкой в войсках национальной гвардии способствуют обеспечению необходимого уровня физической подготовленности военнослужащих и сотрудников для выполнения служебно-боевых задач, должностных (служебных) обязанностей в соответствии с их предназначением.

Постоянное несение службы в условиях роста правонарушений в обществе требует от военнослужащих и сотрудников Росгвардии высокого профессионального мастерства. Однако, систематическое выполнение оперативно служебно-боевых задач с высокими психологическими и физическими нагрузками создает дефицит времени для занятий, поддерживающих работоспособность на высоком уровне, накопленный опыт по разработке программ физической подготовки не в полной мере отвечает требованиям предъявляемым к подготовке специалистов проводящих учебнотренировочные занятия по этой дисциплине.

В данной статье мы постарались расширить научно-педагогические знания в области совершенствования скоростно-силовых качеств и повышения общего уровня физической подготовленности военнослужащих и сотрудников Росгвардии. 
Результаты проведённого тестирования физической подготовленности курсантов в Новосибирском военном институте с различными типами энергообеспечения мышечной системы показали существенные отличия в физическом совершенствовании курсантов в процессе учебно-тренировочных занятий. Путём дифференцированного исследования применения комплексов высокоинтенсивных упражнений, практически подтверждено различие в физическом развитии курсантов в ходе проведения учебных занятий.

На основании проведённого тестирования выявлено соотношение курсантов с преимущественно «аэробным», «смешанным», «анаэробным» типами энергообеспечения мышечной системы. Эти результаты были получены в ходе тестов на определие силовой выносливости определяющих уровень функциональной подготовленности испытуемых. Данная методика дифференцированного применения комплексов высокоинтенсивных упражнений основана на подборе комплексов упражнений из функционального многоборья с учётом сильных и слабых сторон курсантов с различными типами энергообеспечения.

В результате корреляционного анализа мы установили, что энергообеспечение мышечной системы существенно влияет на время выполнения тестов, где курсанты проявляют локальную мышечную выносливость («Отжимания от пола 100 раз», «Приседания 100 раз». Подтягивания в висе на перекладине 50 раз», «Отжимания на брусьях 100 раз»). Причем, чем меньше времени, при выполнении теста, имеется для расслабления мышц, тем больше результат зависим от «мощности гликолитического источника энергообеспечения». Результаты тестов, выполняемых длительное время, но в своей структуре имеющих достаточное время для восстановления мышц за счет переключения на другие мышечные группы («5 подтягиваний 10 отжиманий 15 приседаний», «табата 8 раундов»), либо за счет достаточно длинной фазы расслабления мышцы в цикле движения («бурпи за 7 минут»), во многом зависят от возможностей функции внешнего дыхания. Также установлено, что результаты теста «бег на 3000 метров» могут зависеть как от мощности аэробного источника энергообеспечения, так и от функции внешнего дыхания. Именно при низком уровне первого показателя организм курсантов адаптируется к длительной работе на выносливость за счет повышения функциональных возможностей дыхательных мышц. В тесте «прохождение единой полосы препятствий» определяющую роль играет работоспособность мышц ног, а «подтягивание в висе на перекладине» можно считать универсальным, т.к. данный тест имеет наибольшее количество взаимосвязей с результатами других тестов.

Исходя из вышесказанного, можно сделать вывод о необходимости дополнения общепринятой программы тестирования, отражающей уровень локальной мышечной выносливости и работоспособности функциональных систем. Также необходимо дифференцирование физической подготовки курсантов на основе учета типов энергообеспечения мышц. На основании проведенных экспериментов и анализа литературных источников был выявлен ряд особенностей в физическом развитии курсантов с различными типами энергообеспечения мышечной деятельности. Преимуществами для курсантов различными типами энергообеспечения мышечной деятельности являлись: аэробный тип - предрасположенность к длительной работе умеренной мощности, высокий уровень локальной выносливости мышц, быстрое восстановление от занятия к занятию. Смешанный тип - показал сбалансированный вариант энергообеспечения мышечной деятельности, наиболее приемлемый в выполнении обязательных физических упражнений для проверки физической подготовленности курсантов. Анаэробный тип - который предрасположен к проявлению скоростно-силовых качеств с более высоким уровнем физической подготовленности при выполнении многоповторной работы показывает высокий уровень функциональных способностей дыхательной системы.

Проделанные эксперементы показали, что для курсантов с различными типами энергообеспечения аэробный тип показывает наиболее низкие результаты в тесте 
общих физической подготовленности так как, при физической нагрузке идёт быстрое накопление утомления. Выносливость, как правило, лимитирована высоким уровнем концентрации лактата в мышцах. Требуется длительное время для восстановления.

Таким образом курсанты с аэробный типом показывают рост уровня физической подготовленности и способность обеспечить за счет увеличения силы медленных мышечных волокон уровень функциональных возможностей системы. Следовательно при использовании комплексов из функционального многоборья необходимо применять упражнения, основанные на выполнении большого количества повторений, причем отдых допускать только после отказа мышц или появления достаточно сильной одышки. Курсантам смешанного типа: рост уровня физической подготовленности обеспечивать за счет увеличения силы медленных мышечных волокон, при помощи коротких высокоинтенсивных упражнений. При использовании комплексов из функционального многоборья, применять комплексы, в которых предусмотрено чередование упражнений. Ввиду небольшого количества часов, отведенных для занятий урочного типа, формирующий эксперимент проводился в часы спортивно массовой работы с участие командиров подразделений.

Упражнения из экспериментальной методики были подобраны на основе положительных сдвигов в физическом развитии курсантов. На основании выявленных результатов было разработано три типа коплексов для самостоятельных занятий по теме гимнастика и атлетическая подготовка.

Анаэробный тип: первый комплекс - последовательное выполнении подтягиваний 50 раз, отжимания 100 раз, приседаний 150 раз, с минимальными паузами для отдыха. Второй комплекс - бурпи, выполняется в равномерном темпе с минимальными паузами для отдыха в течение 7 минут. Третий комплекс подтягивания 50 раз, жим гири 16 кг. 100 раз. Для Смешанного типа комплекс последовательно выполнение подтягивания 50 раз, отжимания 100 раз, приседания 150 раз, с минимальными паузами для отдыха.

Полученные результаты показали, что внедрение и применение новых физических упражнений, а также постоянная и систематическая тренировка военнослужащих в процессе служебно-боевой деятельности является важным средством обеспечения их физической готовности к успешным действиям в повседневной учебно-боевой деятельности и боевой обстановке.

$$
\text { *** }
$$

1. Насталение по физической подготовке в войсках национальной гвардии Российской Федерации, приказ №100 от 29.03.2018 г., -78 с.

2. Диссертация. Козлов О.А. «Совершение профессиональной подготовки курсантов войск национальной гвардии Российской Федерации при помощи современных информационных технологий», Саратов. 2017г. - 237 с.

3. Автореферат. Смирнов А. А. «Дифференцироанное применение комплексов высокоинтенсивных упражнений на самостоятельных занятиях у курсантов военного института войск национальной гвардии», Санкт-Петербург. 2018 г. - 25 с.

\section{Ломаева М.В.}

Экономическое воспитание дошкольников: обзор программ и преемственность

Нижнетагильский государственный сочиально-педагогический институт (филиал) ФГАОУ ВО «Российский государственный профессионально-педагогический университет»

(Россия, Нижний Тагил)

doi: 10.18411/lj-05-2021-235

\section{Аннотация}

В статье представлены результаты анализа программ по экономическому воспитанию дошкольников в части их цели, задач, содержания, форм организации 